\title{
ДОСЛІДЖЕННЯ НЕОБХІДНІСТЬ ВДОСКОНАЛЕННЯ ТЕХНОЛОГІЧНИХ ПРОЦЕСІВ ЗБИРАННЯ ГРЕЧКИ
}

\author{
Мікуліна Марина Олександрівна \\ кандидат економічних наук, доцент \\ Сумський національний агарний університет \\ ORCID: 0000-0002-6918-5192 \\ e-mail: marinamikulina1@ukr.net \\ Поливаний Антон Дмитрович \\ студент \\ Сумський національний агарний університет \\ ORCID: 0000-0001-8363-7186 \\ e-mail: polivanui1@gmail.com
}

\begin{abstract}
В статті наведена порівняльна техніко-експлуатаційна та техніко-економічна оцінки варіантів технологій збирання гречки, одна із яких передбачає попереднє обприскування посівів десікантами для подальшого забезпечення прямого комбайнування, а друга - попереднє скошування посівів в валки з наступним їх підбиранням та обмолотом.

Ключові слова: гречка, збирання, альтернативні технології, комплекси машин, показники використання, якісні по-
\end{abstract} казники, економічна ефективність.

DOI: https://doi.org/10.32845/msnau.2021.1.5

Постановка проблеми в загальному вигляді. Проблема полягає в необхідності визначення більш раціонального варіанту технологій збирання гречки, альтернативність яких знаходиться між роздільним (двофазним) способом збирання та прямим комбайнуванням, враховуючи, що крупа із зерна цієї культури використовується для дієтичного харчування.

Аналіз останніх досліджень і публікацій. Дослідження стосовно застосування зернозбиральних комбайнів на збиранні гречки прямим комбайнуванням не проводились, крім того, що згадується [1].

Формулювання цілей досліджень. Встановлення аналітичним шляхом показників використання машинних агрегатів, які застосовуються в технологічних процесах збирання гречки і які дали 6 можливість визначитись 3 більш раціональними схемами збирання цієї культури.

Виклад основного матеріалу.

Не дивлячись на високу цінність виробництво зерна гречки в Україні находиться не належному рівні: врожайність зерна низька, втрати при збиранні великі, а собівартість висока, що в послідуючому проявляється на ціні гречаної крупи. Вирішення проблеми значного збільшення об'ємів виробництва гречки за рахунок підвищення урожайності та зменшення собівартості проведення робіт по вирощуванню гречки сьогодні $€$ актуальним.

Як відомо, до останнього часу практично скрізь застосовувалась традиційна і безальтернативна технологія збирання гречки, яка передбачала скошування рослинної маси (стебла, листя, суцвіття, зерно) у валки, а після ії підсихання до збиральної вологості (вологість стебел18-20\%) підбирання та обмолот валків.

Для забезпечення цієї технології необхідно мати наступні технічні засоби:

- жатку валкову, конструкція якої дозволяла 6 формувати валок необхідної ширини і маси, щоб молотарка комбайна при обмолоті валків була повністю завантажена на робочій швидкості в межах 4-7 км/год;

- комбайн зернозбиральний класу 5-10 кг/с, молотильний апарат якого міг би забезпечити обмолот гречки на оптимальних режимах (лінійна швидкість бил барабана 15-18 м/с, що відповідає частоті обертів барабана діаметром600 мм в діапазоні 480-580 хв-1, а це практично вдвічі менше, ніж при обмолоті пшениці);

- підбирач валків, яким комплектується зернозбиральний комбайн і який забезпечив би якісне підбирання валків гречки.

Для забезпечення технології збирання гречки, яка передбачала б пряме комбайнування (будемо називати її альтернативною технологією), необхідно мати:

- обприскувач (або як самостійна машина або в агрегаті з трактором) для нанесення препаратів (хімічних чи органічних) на рослини з метою прискорення дозрівання чи підсихання рослинної маси;

- комбайн зернозбиральний як і в попередній технології;

- пристрій для зменшення технологічних втрат зерна від дії планок мотовила жатки, якщо вони виявляються значними.

Для об'єктивної і достовірної оцінки технологій необхідно володіти інформацією стосовно технологічних можливостей машин, цін на них для формування необхідного раціонального комплексу машин, володіти методикою порівняльної оцінки типової та альтернативної технології збирання гречки.

Теоретичні передумови по визначенню показників використання машинних агрегатів

Жаткові агрегати. Тяговий опір жаткових агрегатів, які $є$ тягово-приводними машинами, представляє собою суму тягового опору жатки і тягового зусилля, яке міг би додатково розвивати трактор чи інший енергетичний засіб за рахунок потужності, яка витрачається через ВВП.

Для причіпних жаткових агрегатів:

$$
R=R_{f}+R_{i}+R_{в в п}, k H \text {, }
$$

де $R_{f}$ - опір перекочування, кН;

$\mathrm{R}_{i}$ - onip підйому, $\mathrm{kH}$;

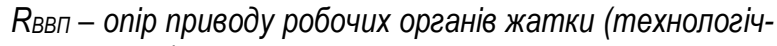
ний оnip), $k \mathrm{H}$. 


$$
R_{f}=\left(G_{\text {eз }}+G_{*}\right)^{*} f, \mathrm{kH}
$$

де $G_{\text {eз }}$ - вага енергетичного засобу, кН;

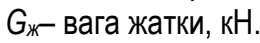

$$
R_{i}=\left(G_{e 3}+G_{*}\right) \frac{\mathrm{i}}{100}, \mathrm{kH}
$$

Потужність, що передається на ВВП для причіпних жаток $N_{B B \Pi}=(0,45-0,59) B_{\kappa}$, КBT, де $B_{\kappa}-$ конструкційна ширина захвата жатки);

Робоча швидкість жаткового агрегату $V_{p}$ повинна забезпечуватися потужністю двигуна:

$$
V_{p} \leq \frac{\left(N_{\mathrm{e}}^{\mathrm{H}} * \xi-\frac{N_{\mathrm{BB}}}{\eta_{\mathrm{BB \Pi}}}\right) * 3,6 * \eta_{\mathrm{Tp}} * \eta_{\sigma}}{R}, \text { км/год., }
$$

Агротехнічно допустима робоча швидкість жаткового агрегату повинна бути в межах $6-10$ км/год.

Зернозбиральні комбайни. Швидкість руху машин, які характеризуються пропускною здатністю їх робочих органів, визначаються, виходячи із цього параметра та енергетичною можливістю двигуна:

$$
V_{p}=\frac{N_{\mathrm{e}}^{\mathrm{H}} * \xi_{\phi}-N_{\mathrm{xp}} * Q_{\mathrm{M}}}{\frac{G_{\mathrm{e}} * f}{\eta_{\mathrm{Tp}} * \eta_{6}}+0,01 * N_{Q_{\mathrm{M}}} * \mathrm{~B}_{\mathrm{p}} * \mathrm{Y}_{\mathrm{pM}}}, \mathrm{M} / \mathrm{C},
$$

де $N_{\mathrm{e}}^{\mathrm{H}}$ - номінальна ефективна потужність двигуна, кВт;

$N_{\text {хр }}$ - питома потужність на холостий привод робочих органів, $\mathrm{KBT}^{*} \mathrm{C} / \mathrm{K}$;

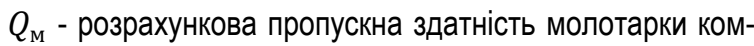
байна при еталонному співвідношенні зерна до соломи 1:1,5;

$G_{\mathrm{e}}$ - експлуатаційна (повна) вага комбайна, кH;

$\eta_{\text {тр }}$ - ККД трансмісії комбайна;

$N_{Q_{M}}$ - питома приведена потужність на одиницю пропускної здатності, кВтc/кг;

$\eta_{6}$-ККД буксування;

$\mathrm{B}_{\text {рж }}$ - робоча ширина захвата жатки, м;

$\mathrm{y}_{\text {рм }}$ - врожайність рослинної маси, ц/га.

Дійсні значення $N_{\text {хр }}$ та $N_{Q_{M}}$ визначаються для кожної моделі комбайна тензометруванням. Для зернозбиральних комбайнів класичної схеми обмолоту $N_{\text {хр }}=(1,8-2,2)$ $\mathrm{KBT}^{*} \mathrm{C} / \mathrm{\kappa r} ; \quad N_{Q_{\mathrm{M}}}=(0-52-0,59) \mathrm{kB} \mathrm{T}^{*} \mathrm{C} / \mathrm{kr}$.

Якщо швидкість руху перевищує агротехнічно допустимий діапазон, то її треба зменшити так, наскільки дозволяє пропускна здатність:

$$
V_{p}=\frac{10 * Q_{\mathrm{M}}}{\mathrm{B}_{\mathrm{p} * \mathrm{~V}_{3}}\left(1+\delta_{\mathrm{c}}\right)}, \mathrm{M} / \mathrm{C},
$$

де $Q_{\mathrm{M}}$ - можлива в даних умовах пропускна здатність комбайна, кг/с;

$\mathrm{y}_{3}$ - врожайність зерна, т/га;

$\delta_{\mathrm{c}}$ - соломистість рослинної маси (відношення маси соломи до маси зерна).

Можлива пропускна здатність молотарки $Q_{\text {м }}$ в залежності від соломистості розраховується за формулою:

$$
Q_{\mathrm{M}}=0,6 Q_{\mathrm{H}}\left(1+\frac{1}{\delta_{\mathrm{c}}}\right), \mathrm{k} / \mathrm{c}
$$

На підбиранні валків швидкість руху комбайна визначається за формулою:

$$
V_{p}=\frac{Q_{\mathrm{M}}}{q_{\mathrm{B}}}, \mathrm{M} / \mathrm{C},
$$

де $q_{\text {в }}$ маса одного метра валка, кг/м.

$$
q_{\mathrm{B}}=\frac{\mathrm{y}_{\mathrm{pm}} * \mathrm{~B}_{\mathrm{p}}}{10}, \mathrm{\kappa} / \mathrm{M}
$$

3 одного боку очевидно, що маса одного метра валка («потужність валка») повинна бути такою, щоб повне завантаження молотарки комбайна здійснювалось при швидкості його руху в межах 4-8 км/год. Зрозуміло, що швидкість повинна бути якомога ближче до меншого значення, оскільки при цьому показники використання комбайна будуть кращі через зменшення часу на непродуктивну роботу.

3 іншого боку велика маса валка може уповільнити час його просихання, а значить і збільшити кількість втрати зерна, а можливо і його якісні показники.

Тому при формуванні валка треба зважувати стан рослинної маси на полі та погодні умови, які складаються на час збирання.

Фактичні затрати часу при проведенні механізованих польових робіт залежать від багатьох факторів. Суттєвий вплив на виробіток машинних агрегатів мають: технічний стан енергетичних засобів і робочих машин, кліматичні, природні і ґрунтові умови, вирощувані культури, сорт, склад агрегату, довжина гонів, організація робіт при проведенні технологічних операцій.

Коефіцієнт використання часу зміни, т:

$$
\mathrm{T}=\frac{\mathrm{T}_{\mathrm{p}}}{\mathrm{T}_{\mathrm{p}}+\mathrm{T}_{\mathrm{xx}}+\mathrm{T}_{3}},
$$

де $\mathrm{T}_{\mathrm{p}}, \mathrm{T}_{\mathrm{xx}}, \mathrm{T}_{3}$ - тривалість відповідно чистої (основної) роботи, холостих поворотів, зупинок через порушення технологічного процесу, год.

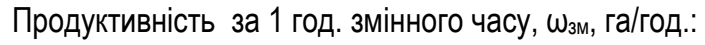

$$
\omega_{3 M}=0,1^{*} B_{p}{ }^{*} V_{p}{ }^{*} T
$$

де $\mathrm{B}_{p}$ - середнє арифрметичне значення робочої ширини захвату жатки, $\mathrm{M}$,

$V_{p}$ - середнє ариффметичне значення робочої швидкості агрегату, км/год.

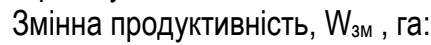

$$
W_{\text {зм }}=\omega_{\text {зм }}{ }^{*} T_{\text {зм, }}
$$

де Тзм - тривалість зміни, год.,

Потужність, що затрачується на роботу агрегату, $\mathrm{N}_{\mathrm{e}}$, $\mathrm{kBT}$.

$$
\mathrm{N}_{\mathrm{e}}=\frac{k * B_{p} * V_{p}}{3.6}+N_{\mathrm{BB \Pi}}+\frac{\left(G_{\mathrm{T}}+G_{\varkappa}\right) * f * V_{\mathrm{p}}}{3.6 * \eta_{\delta} * \eta_{\mathrm{Tp}}},
$$

Де k - питомий опір жатки при скошуванні стеблостою, кH/м. В даній ситуації можна брати максимальне значення $\mathrm{k}=1,5 \mathrm{kH} / \mathrm{M}$;

$\mathrm{N}_{\text {вв }}$ - потужність на привод механізмів жатки, кВт. Із довідкової літератури $\mathrm{N}_{\text {вв }}=2,9$ кВт;

$\mathrm{G}_{\mathrm{T}}$ - експлуатаційна вага трактора, $\mathrm{kH}, \mathrm{G}_{\mathrm{T}}=40 \mathrm{kH}$;

$\mathrm{G}_{*}$ - конструкційна вага жатки, кH, $\mathrm{G}_{*}=14 \mathrm{kH}$;

$\mathrm{f}$ - коефріцієнт опору перекочуванню. На перезволоженому ґрунті можна прийняти $f=0,12$;

$\eta_{\delta}$ - ККД буксування. При буксуванні рушіїв трактора $12 \%$ $\eta_{\delta}=0,88$ 
$\eta_{\text {тр }}$ - ККД трансмісії. Для колісних тракторів $\eta_{\text {тр }}=0,92$.

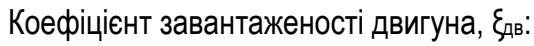

$$
\xi_{\text {дв }}=\frac{N_{\mathrm{e}}}{N_{\mathrm{eH}}},
$$

де $\mathrm{N}_{\text {ен }}$ - номінальна ефрективна потужність двигуна, кВт.

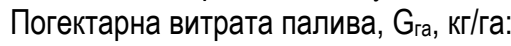

$$
\mathrm{G}_{\mathrm{ra}}=\frac{N_{\mathrm{e}}^{\mathrm{H}} * g * \xi_{\text {дв }}}{1000 * \omega_{3 \mathrm{M}}},
$$

де $\mathrm{g}$ - питома витрата палива двигуном, г/кВТ год.

Визначення техніко-економічних показників машинних агрегатів

При оцінці ефективності використання МА, пов'язаного з виконанням польових механізованих робіт, використовують головним чином один критерій оптимізації - приведені питомі витрати, які включають в себе прямі експлуатаційні витрати та ефективність капіталовкладень.

Прямі експлуатаційні витрати коштів передбачають визначення таких показників:

- відрахування на реновацію (накопичення коштів для заміни зношеної або застарілої техніки);

- відрахування на підтримання роботоздатності машин (проведення планових технічних обслуговувань, поточних ремонтів при появі такої необхідності);

- витрату коштів на оплату працівників на обслуговуванні МА

- витрату коштів на придбання паливно-мастильних матеріалів (ПММ).

При визначенні рівня ефективності використання нових машин, коли потрібно врахувати нинішні та минулі уречевлені витрати, розрахунки показників порівнювальних агрегатів ведуть за приведеними витратами. В даному випадку формулу цілі математично можна виразити наступною формулою:

$$
n_{M A}=f\left(C_{n u m}, K_{в \kappa}\right) \rightarrow \min
$$

де пмА - питомі приведені витрати на машинний агрегат, грн./га (т, т·Км);

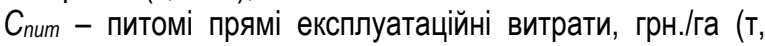
$\mathrm{T} \cdot \mathrm{KM})$;

$K_{\text {вк }}$ капітальні вкладення, пов'язані з придбанням технічних засобів, грн/га (т, т·км).

Прямі питомі експлуатаційні витрати визначають за формулою:

$$
C_{\text {num }}=C_{\text {оп }}+C_{\text {пмм }}+C_{P}+C_{\text {то, }} \text { грн/га, }
$$

де Соп - оплата праці обслуговуючого МА персоналу з нарахуваннями на соціальні потреби, грн/га;

Спмм - вартість витрачених паливно-мастильних матеріалів, грн/га;

$C_{P}$ - відрахування на реновацію технічних засобів, які входять до складу МА, грн./га;

Сто - відрахування на поточний ремонт (ПР) та технічне обслуговування (ТО), грн/га.

Витрата коштів, пов'язаних з оплатою праці обслуговуючого персоналу:

$$
\mathrm{Con}_{\mathrm{n}}=\mathrm{C}_{0}+\mathrm{C}_{\partial}+\mathrm{C}_{\mathrm{c}} \text {, грн./га, }
$$

де $\mathrm{C}_{-}$- основна заробітна плата, грн./га,

С - додаткова заробітна плата, грн./га,

Ссз-відрахування на соціальні заходи, грн./га.

$$
\mathrm{C}_{0}=\frac{m_{1} \cdot \Pi_{1}+m_{2} \cdot \Pi_{2}+\ldots+m_{6} \cdot \Pi_{n}}{\omega_{\text {зм}}}, \text { грн/га, }
$$

де $m_{1}, m_{2}, \ldots, m_{6}$ - кількість робітників, які обслуговують МА окремо по кожній кваліфікації (розряду);

$\Pi_{1}, \Pi_{2}, \ldots, \Pi_{6}$ - оплата праці за годинну норму виробітку робітника і-ї кваліфрікації від першого до шостого розряду, грн./год.;

$\omega_{з м}-$ продуктивність за 1 годину змінного часу, га/год.

$$
\mathrm{C}_{\partial}=\mathrm{C}_{0}{ }^{*} k_{3 n}, / 100, \text { грн./га, }
$$

де $k_{3 n}$ - плановий коефріцієнт нарахування додаткової заробітної плати, \%.

$$
\mathrm{C}_{c 3}=П Ф+Ф С С+Ф 3 . \text { грн./га, }
$$

де ПФ, ФСС. ФЗ - відрахування відповідно в пенсійний фонд, фонд соціального страхування та фонд зайнятості, грн./га.

$$
C_{c 3}=Ф О П\left(k_{n \phi}+k_{\phi c c}+k_{\phi 3}\right) / 100, \text { грн./га, }
$$

де $k_{n ф}$ - коефріцієнт відрахування в пенсійний фонд, $\left(k_{n \phi}=32,3 \%\right)$,

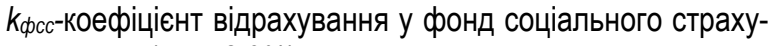
вання, $\left(k_{\phi c c}=2,9 \%\right)$,

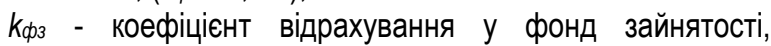
$\left(k_{\phi_{3}}=1,6 \%\right)$,

ФОП - фронд заробітної плати, грн./га.

$$
Ф О П=C_{0}+C_{\partial}, \text { грн./га }
$$

Вартість паливно-мастильних матеріалів визначається за формулою:

$$
C_{п м M}=Ц_{\kappa} \cdot G_{2 a}=k_{u} \cdot Ц_{\partial n} \cdot G_{2 a}, г р н / r a,
$$

де Цк - комплексна ціна палива, грн/кг;

$\mathrm{G}_{2 a}$ - погектарна витрата палива, кг/га;

$k_{u}$ - поправочний коефріцієнт на ціну палива;

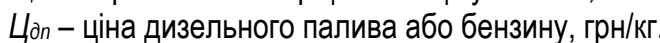

Комплексна ціна одиниці маси палива враховує крім основного палива витрати на моторні, трансмісійні, індустріальні, пластичні, консерваційні мастила. Це здійснюється шляхом введення поправочного коефріцієнта $k_{u}$ до ціни на основне паливо [ 7 ].

Якщо, наприклад, ціна дизельного палива на ринку нафтопродуктів дорівнює Ц паливно-мастильних матеріалів для зернозбиральних комбайнів складе $\bigsqcup_{\kappa}=1,307 \cdot 20=26,14$ грн./кг.

Зважаючи на те, що капітальні ремонти в сучасних умовах не виконуються, то амортизаційні відрахування складаються тільки з відрахувань на реновацію, кошти з яких потрібні на заміну технічних засобів на більш досконалі або рівнозначні.

Відрахування на реновацію машин в агрегаті визначають загальною формулою:

$$
\mathrm{C}_{P}=\frac{1}{100 \cdot \omega_{3 \mathrm{M}}}\left(\frac{\mathrm{Б}_{T} \cdot a_{P T}}{T_{T}}+\frac{Б_{M} \cdot n_{M} \cdot a_{P M}}{T_{M}}\right), \mathrm{rpH} / \mathrm{ra},
$$

де Бт, Бм - балансова вартість відповідно трактора, робочої машини, \%;

ар $T$, ар м - норма відрахування на реновацію відповідно трактора, робочої машини, \%; 
$T_{T}, T_{M}$ - нормативне річне завантаження відповідно трактора, робочої машини, год.;

nм - кількість робочих машин в складі агрегату.

Відрахування на поточний ремонт та технічне обслуговування визначається за формулою:

$$
\text { Сто }=\frac{1}{100 \cdot \omega_{3 \mathrm{M}}}\left(\frac{\mathrm{Б}_{T} \cdot a_{T O T}}{T_{T}}+\frac{Б_{M} \cdot n_{M} \cdot a_{T O M}}{T_{M}}\right), \text { грн/га, }
$$

де ато т, ато м - норма відрахування відповідно на трактор, робочу машину, \%.

Питомі приведені витрати на машинний агрегат визначаються за формулою:

$$
n=C_{\text {num }}+E \cdot K_{в к}, \mathrm{rpH} / \mathrm{ra},
$$

де $E$ - нормативний коефіцієнт ефективності капітальних вкладень $(E=0,15)$;

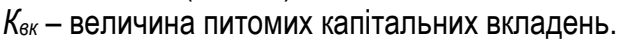

Капітальні вкладення визначаються за формулою:

$$
\mathrm{K}_{\mathrm{BK}}=\frac{1}{\omega_{3 \mathrm{M}}}\left(\frac{Б_{T}}{T_{T}}+\frac{\mathrm{Б}_{M} \cdot n_{M}}{T_{M}}\right), \text { грн/га, }
$$

Найбільш економічно доцільним в застосуванні в конкретних умовах $€$ той машинний агрегат, у якого приведені витрати найменші.

Дамо порівняльну оцінку технологіям методом математичного моделювання

Вихідні дані для розрахунків:

1. Поле прямокутної форми площею 100 га.

2. Гречка сорту Ярославна 3 врожайністю зерна 20 ц/га.

3. Соломистість рослинної маси (відношення маси соломи до маси зерна) - 2,0.

4. Склади машинних агрегатів:

- обприскування посівів: трактор МТЗ-82.1; обприскувач ОПК-800-12; скошування маси у валки: трактор МТЗ82.1; жатка ЖВП-4,9;

- зернозбиральний комбайн «Палессе» GS-812, обладнаний підбирачем валків П3-3,4-01.

Техніко-експлуатаційні показники,визначені аналітичним шляхом та за результатами експериментальних досліджень, наведені в таблиці 1.

Таблиця 1 - Техніко-експлуатаційні показники використання машинних агрегатів

\begin{tabular}{|c|c|c|c|}
\hline Технологічна операція & Склади агрегатів & $\begin{array}{c}\text { Продуктивність за 1 год. } \\
\text { змінного часу, } \frac{\text { га/год }}{\text { т/год }}\end{array}$ & $\begin{array}{c}\text { Витрата палива, } \\
\frac{\text { кг/га }}{\text { кг/т }}\end{array}$ \\
\hline 1.Обприскування & MT3-82.1+ОПК-800-12 & 11,0 & 0,34 \\
\hline 2.Скошування в валки & MT3-82.1+ЖBП-4,9 & 2,4 & 2,7 \\
\hline 3.Збирання: & GS-812+П3-3,4-01 & 3,4 & $\frac{5,9}{3,0}$ \\
- роздільним способом & GS-812 & $\underline{6,8}$ & $\frac{5,4}{2,7}$ \\
\hline
\end{tabular}

Результати математичного моделювання порівняльної оцінки комплексів машин.

Техніко-економічні показники комплексів машин для збирання гречки за різними технологіями наведені в табл. 2.

Як видно із таблиці 2 по критеріях прямих експлуатаційних та приведених витрат більш економною $є$ технологія, яка передбачає десикацію посівів. В порівнянні з технологією, яка передбачає скошування гречки в валки, вона має перевагу в 157 грн/га, а в розрахунку на всю площу -15720 грн.

Але треба мати на увазі, що обов'язковою умовою при використанні першої технології є обладнання навігаційною системою для забезпечення точності стикових проходів агрегату і недопущення огріхів (на них комбайни заб'ються миттєво) та надлишкового нанесення робочої рідини на рослини в зоні перекриття робочих проходів агрегату. В цій ситуації рушіями трактора приминається близько 12\% посівів (по чотири рядки на кожному проході). Це означає перевитрати на насіння при його ціні 8 тис.грн. за одну тонну при нормі висіву 100 кг/га складають 96 грн/га, а недоотримання коштів від втраченого зерна при ціні 3 тис.грн. за 1 тонну та врожайності 20 ц/га складе 720 грн/га. Через втрати зерна на насіння збитки складуть в сумі 816 грн/т, а на всю площу посіву 81,6 тис.грн.

Таблиця 2 - Техніко-економічні показники використання комплексів машин

\begin{tabular}{|l|c|c|}
\hline \multicolumn{1}{|c|}{ Показники } & \multicolumn{2}{|c|}{ Комплекси машин різних варіантів технологій } \\
\cline { 2 - 3 } & $\begin{array}{c}\text { Проектна технологія: } \\
\text { MT3-82.1+OПК-800-12+ } \\
\text { GS-812 }\end{array}$ & $\begin{array}{c}\text { Традиційна технологія: } \\
\text { MT32.1+ЖВП-4,9+ } \\
\text { GS-812+П3-3,4-0,1 }\end{array}$ \\
\hline 1. Капітальні вкладення, грн/га & 1046 & 1095 \\
\hline 2.Відрахування на реновацію, грн/га & 261,6 & 317,3 \\
\hline 3.Відрахування на поточний ремонт та технічне обслуговування, грн/га & 154,8 & 162,1 \\
\hline 4. Оплата праці, грн/га & 11,2 & 19,0 \\
\hline 5. Витрати на паливо, грн/га & 81,1 & 111,8 \\
\hline 6.Прямі питомі експлуатаційні витрати, грн/га & 508,7 & 610,2 \\
\hline 7. Приведені витрати, грн/га & 792,3 & 949,5 \\
\hline
\end{tabular}


Як показали польові спостереження, втрати зерна при скошуванні жаткою в валки і їх підбиранні комбайном не перевищують 3\%(якщо не порушені агротехнічні вимоги), але зовсім не відомі втрати зерна при прямому комбайнуванні посівів після десикації. Можна стверджувати апріорі, що вони будуть не меншими. Виробничі моменти в процесі проведення досліджень представлені на рисунках 1-3.

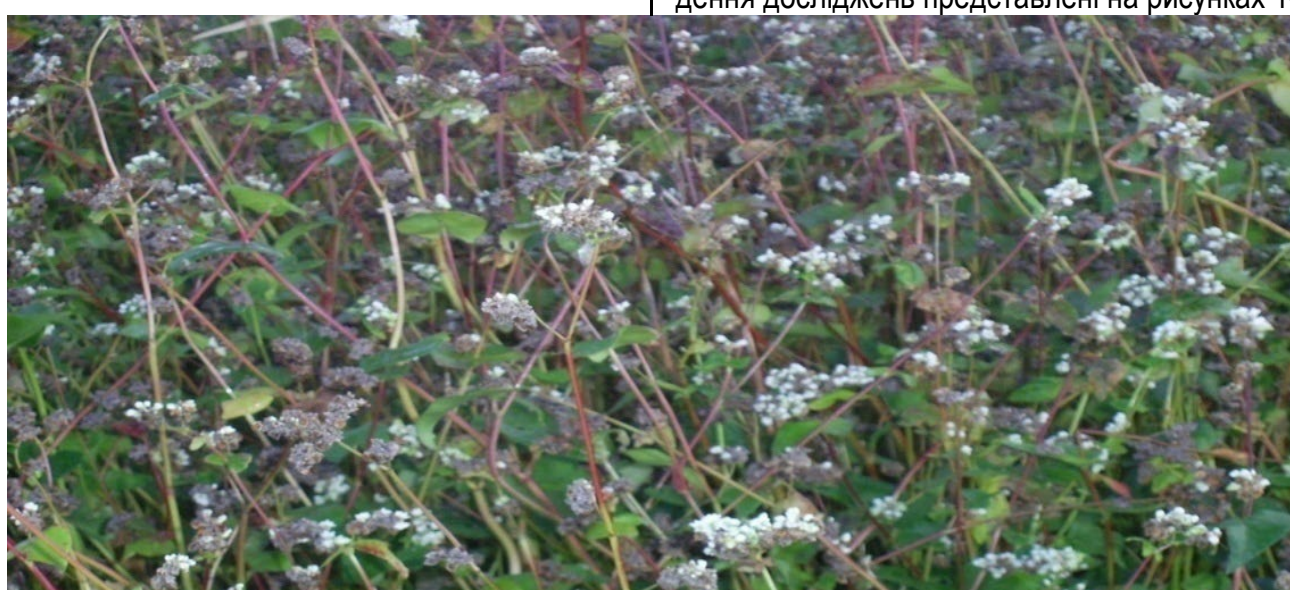

Рис.1 - Посіви гречки до обробітку хімічними препаратами

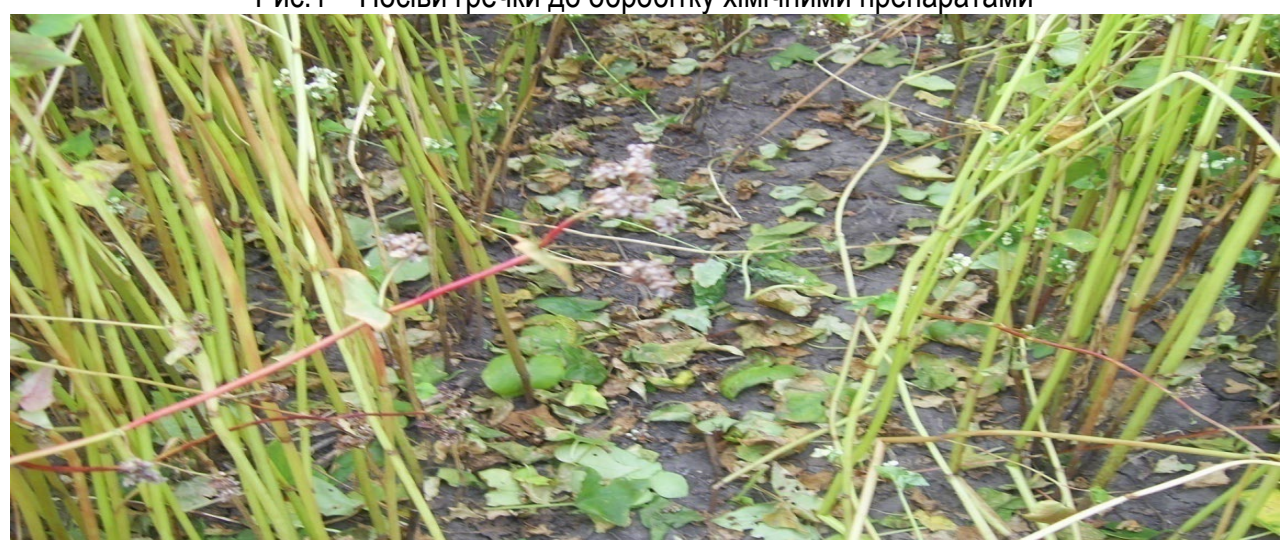

Рис.2 - Посіви гречки після обробітку хімічними препаратами

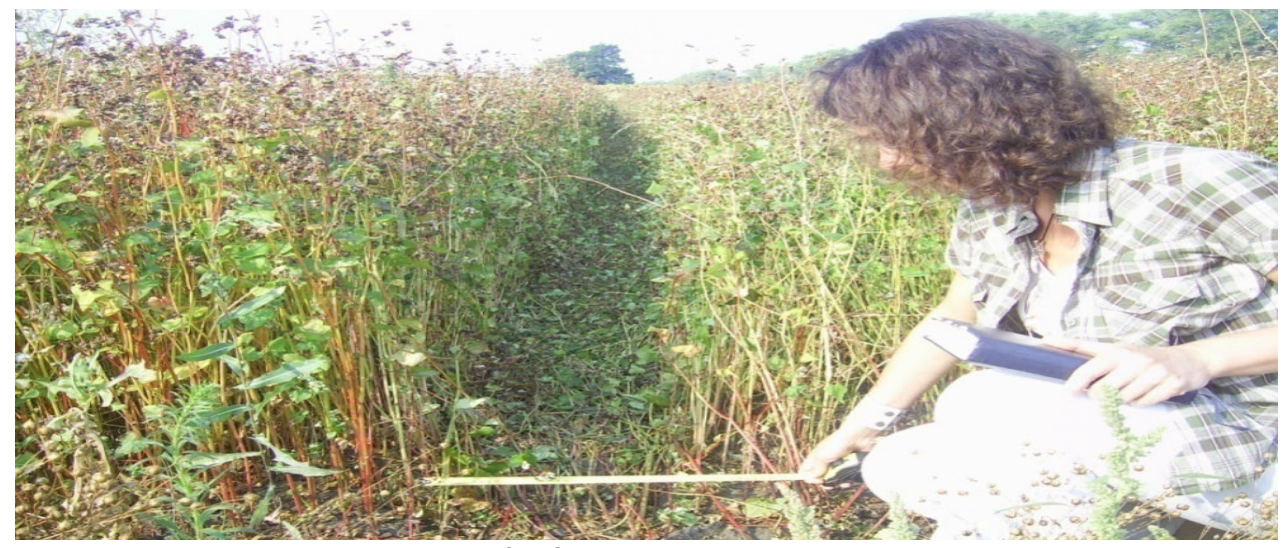

Рис.3 - Замір параметрів колії

$€$ ще одна деталь не на користь першої технології витрата коштів на придбання десикантів. Вони складають від 160 до 336 грн/га в залежності від типу препаратів та норми внесення.

Висновки.

1. Балансова вартість комплексів машин, що забезпечують реалізацію обох варіантів технологій , практично однакова. Різниця складає 53 грн/га.

2. Витрати на паливо при застосуванні традиційного варіанту технологій більші в 1,4 рази в порівнянні з альтернативним.
3. Собівартість збирання гречки традиційним способом, визначена за прямими експлуатаційними витратами, на 20 \% вища ніж проектного (950 проти 792 грн/га).

4. Традиційна технологія не передбачає внесення будь - яких препаратів впливу на стан рослин на корені, а другий - внесення десікантів, на які потрібно витрачати 160 336 грн/га в залежності від виробничих обставин.

5. Втрати зерна від застосування традиційного варіанту технологій будуть в межах агровимог (не більше 3 \%). Експериментальний варіант технологій допускає механічні втрати зерна та насіння на суму приблизно 800 грн/га. Для 
встановлення величини технологічних втрат зерна під дією робочих органів жатки комбайна для експериментального варіанту технологій необхідно провести додаткові експериментальні дослідження.
6. Якщо мати на увазі, що гречана крупа повинна використовуватись для дієтичного харчування, то проектний варіант технологій скоріше всього не має права на існування.

\section{Список використаної літератури.}

1.Ефименко Д.Я., Барабаш Г.И. /Гречиха. - М.: Агропромиздат, 1990.-192 с., ил.

2.Мельник І.І., Тивоненко І.Г., Фришев С.Г. та ін. Інженерний менеджмент / За ред. І.І.Мельника. Навчальний посібник. - Вінниця: Нова Книга, 2007.- 536 с.

3. Г.І. Барабаш, М.О. Мікуліна / Залежність техніко-економічних показників використання зернозбиральних комбайнів від рівня врожайності озимої пшениці // Вісник Сумського Національного Аграрного Університету, серія «Механізація та автоматизація виробничих процесів». - 2019. - №3 (37). - С. 31-33

4.Орманджи К.С. Методика разработки операционной технологии механизированных полевых работ//К.С.Орманджи, Ю.К.Киртбая, Г.И.Барабаш.- М.:ПМУ ЦОПКБ ВИМ, 1982.- 192 с.

5.Методика государственного сортоиспытания сельскохозяйственных культур. - М.: Колос, 1971.- 248 с.(Вып.1).

6. М.О. Мікуліна, Г.І. Барабаш / Вплив типу рушія трактора на показники використання орних агрегатів плугів,// Збірник тез доповідей по матеріалах 25-ї міжнародної наукової конференції «Технологии XXI века», (15-20 вересня 2019 р., м. Суми, м. Одеса)/ ч.1. - Суми: СНАУ, 2019. С.-35

7. Г.І. Барабаш, М.О. Мікуліна / Залежність техніко-експлуатаційних показників орних агрегатів // Матеріали II Всеукраїнської науково-практичної конференції «Сучасні моделі розвитку агропромислового виробництва : виклики та перспективи», Випуск 2 Глухів : ГАТІ ім. С.А. Ковпака СНАУ, 2019. С. 10-16

Mikulina M.A., Sumy National Agrarian University (Ukraine)

Polyvanyi A.D., Sumy National Agrarian University (Ukraine)

\section{Research the need for improvement of the technological processes of cleaning bucket}

The article presents a comparative technical and operational and technical and economic evaluation of buckwheat harvesting technologies, one of which involves pre-spraying crops with desiccants to further ensure direct combining, and the second - premowing crops in rolls, followed by their selection and threshing.

The problem in general form. The problem is to determine a more rational version of buckwheat harvesting technologies, the alternative of which is between a separate (two-phase) method of harvesting and direct combining, given that grain groats of this crop are used for dietary nutrition.

Formulation of research goals. Establishment of analytical indicators of the use of machine units, which are used in the technological processes of harvesting buckwheat and which would make it possible to determine more rational schemes for harvesting this crop.

Despite the high value, buckwheat grain production in Ukraine is not at the proper level: grain yield is low, losses during harvesting are large, and the cost is high, which is subsequently reflected in the price of buckwheat. Solving the problem of significantly increasing the production of buckwheat by increasing yields and reducing the cost of work on growing buckwheat is relevant today.

As you know, until recently, almost everywhere used traditional and non-alternative technology of harvesting buckwheat, which involved mowing the plant mass (stems, leaves, inflorescences, grain) in rolls, and after drying to harvest moisture (stem moisture 1820\%) picking and threshing rolls.

For an objective and reliable assessment of technology it is necessary to have information about the technological capabilities of machines, their prices to form the necessary rational set of machines, to have a method of comparative evaluation of typical and alternative technology of buckwheat harvesting.

Theoretical prerequisites for determining the use of machine units

Reaper units. The traction resistance of reaper units, which are traction-driving machines, is the sum of the traction resistance of the reaper and the traction force that could be further developed by a tractor or other energy source due to the power expended through GDP.

Key words: buckwheat, harvesting, alternative technologies, machine complexes, indicators of use, qualitative indicators, economic efficiency.

Дата надходження до редакції: 23.02.2021 